\title{
O DUPLO COMO PARÓDIA EM O ANO DO
}

DILÚVIO

THE DOUBLE AS PARODY IN THE YEAR OF THE FLOOD

Melissa Cristina Silva de Sá*

RESUMO: O Ano do Dilúvio, da canadense Margaret Atwood, é uma distopia na qual nescentes do grupo cujo líder, Adam One, já tinha previsto que um "Diḱvio Seco" atingiria a humanidade. Através dos sermões como pela narrativa de outras personagens, o leimundo distópico: aquele do capitalismo exacotástrofe final e aquele com a humanidade quase diOra neste trabalho é analisar como a narrativa de Adam or sermões cristãos. Conceituand pa um a partir de Ling pretendo discutir como a quebra de a presença couñ ce paradoxo, o texto chama atença para sua próp ía condiçás como se para crando um efeito eśético que rompe com a narrativa codiciotexto, crinc, o um efeito estélico que rompe com a narrativa tradicioprese mesmo tempo en que a endossa. Esse efilo de duplo textuat, presente en outras obras da autora, en O Ano do Dilúvo é uilizado para questionar a suposta naturalidade dos discursos da religiá e da ciencia, enfatizando como o quato quanto a fição.

PALAVRAS-CHAVE: paródia; metaficção; duplo.
* melisacdesa@gmail.com

Feutoranda em Literaturas de Língua Inglesa pela Universidade Federal de Minas Gerais (UFMG) e mestre em Estudos Literários pela mesma instituiçăo. Professora de língua inglesa no Instituto Federal de Minas Gerais (IFMG).

ABSTRACT: Margaret Atwood's The Year of the Flood presents a dystopia in which humanity has been wiped out by a nameless plague and few huma curvived Among them are the remaining mempers and gious group The gious dy for in fine 列 tive is a parody of Chistion

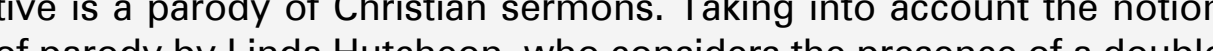
discours in every pardy, lintend to discuss how the breaking ouble discourse Through this paradox, the sext calls attention to its own condition as pection as at the same time it endors it This effect of textual double, present in ther ther works by the author, in The Year of the flood is used to question the

KEYWORDS: parody; metafiction; double. 
1. Apesar de utilizar o título em português ao longo do artigo, a partir da edição britânica de 2009. As traduções de trecho apresentadas são feitas de forma livre. A grafia dos nomes próprios segue a edição mencionada.
A temática do duplo é recorrente à obra da canadense Margaret Atwood. Seus romances frequentemente abordam questões relacionadas de diversas formas: personagens com o mesmo nome, sombras, fantasmas, lembranças reprimidas. No entanto, o uso mais marcante do duplo em Atwood é certamente o textual, especialmente o que diz respeito à intertextualidade e à paródia. Essa última, característica marcante do pós-modernismo canadense de que Atwood faz parte, está presente em textos que reverberam, se apropriam e se moldam a outros textos. Não raro, os romances de Atwood são metaficcionais.

O Ano do Dilúvio ${ }^{1}$ apresenta sua premissa de paródia já no título. O dilúvio mencionado faz referência ao dilúvio bíblico, que, no Antigo Testamento, apresenta a destruição da humanidade pela água, deixando como sobreviventes apenas Noé e sua família. No gênero distópico, a palavra dilúvio carrega a prerrogativa da destruição em massa e da extinção da espécie humana. No entanto, em O Ano do Dilúvio, essa destruição se apresenta também como paródia: trata-se, afinal, do Dilúvio Seco, a crença apocalíptica do grupo religioso Jardineiros de Deus. A quebra de expectativa gera estranhamento: o dilúvio do romance é ao mesmo tempo o aguaceiro que traz catástrofe no sentido bíblico e um outro, o cataclismo seco. Esse duplo significado coexiste em $O$ Ano do Dilúvio e é com base nessa tensão que a paródia se faz no romance, tornando possível a reflexão sobre a construção da própria narrativa, uma vez que o duplo textual cria um efeito estético que, da mesma maneira que endossa a narrativa tradicional (a associação de dilúvio com catástrofe), também mostra que essa narrativa é artificial ${ }^{2}$ (essa associação só é feita porque o discurso religioso lhe dá esse significado). É essa relação de duplo textual e metaficção que será o foco deste artigo, a partir da leitura dos sermões do personagem Adam One.

Como distopia, O Ano do Dilúvio apresenta um futuro próximo em que a humanidade é dizimada por uma causa desconhecida. Quase toda a população morre misteriosamente em decorrência de uma doença que se espalha rapidamente a nível global e os poucos a sobreviver o fazem de maneira precária em meio a um mundo em ruínas. $\mathrm{O}$ romance se desenvolve alternando o passado e o presente das personagens principais, Toby e Ren, e o leitor acompanha a trajetória dessas duas mulheres desde a juventude e a infância, respectivamente, num mundo extremamente capitalista que valoriza o discurso científico em detrimento da arte e que isola a população em Compounds (condomínios de alta segurança onde os ricos ligados a grandes corporações vivem) e Pleeblands (os restos das grandes cidades onde a população pobre faz as vezes de cobaia). A ausência de Estado garante que uma polícia privada, os CorpseCorps, monitorem as atividades das pessoas de acordo com seus próprios interesses. Toby e Ren, mulheres que lidam com a pobreza, a violência e
2. Conforme o vocabulário empregado por Linda Hutcheon no Canadian Postmodern. 
3. BOUSON. "'We're using up the Earth. It's almost gone': A Return to the Post-Apocalyptic Future in Flood", p. 10, tradução livre.

4. Para uma maior discussão sobre $o$ gênero distopia e suas implicações em debates políticos e sociais, ver: MOYLAN. Scraps of the Untainted Sky: Science Fiction, Utopia, Dystopia. o abuso em algum ponto de suas vidas, encontram um porto seguro ao se juntarem aos Jardineiros de Deus, uma religião que mistura ecologia com cristianismo.

Brooks Bouson aponta como, em O Ano do Dilúvio, Atwood "questiona a própria sobrevivência da humanidade numa era de destruição ambiental, consumo excessivo, experimentos biotecnológicos não-regulamentados e vírus pandêmicos". ${ }^{3}$ Essa descrição dificilmente se mostra estranha à realidade das primeiras décadas do século XXI, fazendo da distopia da autora canadense um excelente ponto de partida para comentar os maiores medos e anseios dessa época. A estrutura fragmentada do romance ainda corrobora para a representação da contemporaneidade, utilizando o exagero característico do gênero para produzir o necessário distanciamento no leitor a fim de que uma reflexão crítica se produza. ${ }^{4}$

A possibilidade de sobrevivência das duas protagonistas no ambiente hostil pós-catástrofe, em que há a presença de criminosos sobreviventes além das já mencionadas dificuldades ambientais, se faz pelo senso de comunidade aprendido e desenvolvido durante os anos em que elas fizeram parte dos Jardineiros de Deus. Andrew Hoogheem defende a ideia de que o discurso religioso torna possível sobrevivência em O Ano do Dilúvio ao enfatizar como as crenças e práticas do grupo mencionado possibilita que seus remanescentes sejam eles ainda membros ativos ou não - se adaptem ao ambiente. ${ }^{5}$ As habilidades de contar histórias e compartilhar experiências constituem, segundo autores como Brian Boyd, uma adaptação da espécie humana derivada das brincadeiras entre animais que possibilita que tenhamos foco, percepção do mundo à nossa volta e desenvolvamos a capacidade de tecer hipóteses. Para Hoogheem, as crenças dos Jardineiros de Deus corroboram essa ideia, pois fazem da religião, prática derivada da ficção e da imaginação, uma estratégia de sobrevivência.

Hannes Bergthaller também ressalta a importância da religião dentro de $O$ Ano do Dilúvio. Para o crítico, "os Jardineiros sobrevivem por causa de suas crenças apocalípticas”, uma vez que sua crença atribui significado à sustentabilidade: "Não é suficiente apenas sobreviver - o que é necessário é uma ordem simbólica dentro da qual o fato de sobreviver pode ser significativo e "bom". ${ }^{6}$ Ao transformar o pensamento ecológico em uma religião, os Jardineiros de Deus garantem um sistema em que esses preceitos sejam obedecidos sem ressalvas, uma vez que a visão cristã de um deus onipresente, onipotente e benevolente oferece consolo e propósito para as ações pró-meio ambiente. Dessa forma, a ação é atribuída de significado e se torna um fim em si mesma.

É importante ressaltar que as duas protagonistas do romance possuem uma relação dúbia com a religião. Toby é abrigada pelos Jardineiros de Deus após reagir violentamente
5. HOOGHEEM. "Secular Apocalypses: Darwinian Criticism and Atwoodian Floods", p. 64, tradução livre.

6. BERGTHALLER. “Housebreaking the Human Animal: Humanism an Margaret Atwood's Oryx and Crake and The Year of the Flood", p. 78 tradução livre. 
7. ATWOOD. The Year of the Flood, $\mathrm{p}$. 113 , tradução livre.

8. ATWOOD. The Year of the Flood, $\mathrm{p}$. 279 , tradução livre. a um chefe abusivo e, jurada de morte, permanece entre o grupo religioso a fim de se proteger. $\mathrm{O}$ ambiente seguro propicia o desenvolvimento de suas habilidades na área da saúde e Toby se torna uma espécie de curandeira; anos depois, é elevada à categoria de Eve Six, uma posição de liderança entre os Jardineiros. No entanto, Toby carrega consigo um grande ceticismo em relação ao credo daqueles com quem vive: "Toby podia identificar uma farsa quando via uma, sendo uma farsa ela mesma". 7 Para ela, a fé dos Jardineiros de Deus serve apenas para organizar a vida em sociedade e evitar que as pessoas hajam de forma violenta e irresponsável.

Já Ren chega aos Jardineiros de Deus com sua mãe ainda na infância, depois que esta fugiu de um Compound para viver com seu amante entre o grupo religioso. Aprendendo sobre os preceitos da religião na escola religiosa comunitária, Ren aceita os princípios ensinados pelos Adams e Eves e os carrega durante a vida, mesmo após retornar ao Compound já adolescente. Ren não se mostra especialmente religiosa ao longo do romance, mas reproduz ditados e crenças dos Jardineiros de Deus: "Adam One costumava dizer: se você não pode parar as ondas, vá navegar... que significava que mesmo coisas ruins fazem coisas boas porque elas são um desafio e nem sempre se sabe o bem que elas podem trazer". "Atwood não retrata os membros [dos Jardineiros de Deus] como crentes puros e devotos. Eles não são heróis, mas pessoas cheias de dúvida, desesperadas, frustradas e (aparentemente) impotentes", diz a crítica Katarina Ladubova. ${ }^{9}$ Dessa forma, ao mesmo tempo que a narrativa apresenta a religião como uma ferramenta de sobrevivência no ambiente distópico, também discute as inconsistências, contradições e problemáticas da prática religiosa através de suas personagens.

Perpassando essas duas narrativas está a figura de Adam One, líder espiritual e político dos Jardineiros de Deus cuja figura messiânica é cercada de mistérios e questionamentos. Tratando-se de um cientista dos Compounds que abandona a lógica corporativa para perseguir seus ideais éticos, Adam One carrega um passado que suscita a curiosidade de céticos como Toby. Após um discurso claramente manipulado, que omitia e modificava informações, Adam One confessa: "Eu me desculpo pela intromissão da ficção. Eu devo algumas vezes dizer coisas que não são transparentemente honestas. Mas é para o bem maior". ${ }^{10}$ Sua aparência física de messias, com direito a barba abundante e túnica simples, é essencial para conferir o aspecto cristão à religião criada por ele, que se apega à sua figura paródica de Jesus Cristo.

A fala parabólica é outra característica que confere a Adam One um status diferenciado dos demais Adams e Eves, uma estratégia importante que o coloca como detentor do poder simbólico sobre os demais membros do grupo. Ao tornar
9. LADUBOVA. "Power, Pain and Manipulation in Margaret Atwood's Flood", p. 137-138, tradução livre.

10. ATWOOD. The Year of the Flood, p. 184, tradução livre.
EM TESE

BELO HORIZONTE
JAN.-ABR. 2017 
11. BERGTHALLER. “Housebreaking the Human Animal: Humanism an Margaret Atwood's Oryx and Crake and The Year of the Flood", p. 739, tradução livre. seus preceitos ecológicos em uma religião, Adam One apaga a necessidade de conscientização individual, uma vez que reciclar, reaproveitar e não utilizar produtos de origem animal passa a ser não uma escolha, mas uma obrigação prescrita. Assim, ele assegura que seus valores serão seguidos sem quaisquer problematizações. $\mathrm{O}$ tema que se repete na fala de Adam One é o da "reconciliação da natureza dos seres humanos como seres biológicos evoluídos, com todas as fragilidades e falhas implicadas, com suas necessidades por uma ordem da imaginação que transcende e, por assim dizer, extenua as características biológicas". ${ }^{11} \mathrm{O}$ aspecto transcendental é o que possibilita que suas ideias ecológicas sejam seguidas. A caracterização ambígua do personagem, como crente devoto e cientista manipulador de massas, reforça o aspecto paródico de sua figura, que passa a incorporar, além do messias salvador, também a imagem do cientista louco.

Cada capítulo de O Ano do Dilúvio é introduzido por um hino de louvor dos Jardineiros de Deus e um posterior sermão de Adam One. Os títulos dos capítulos são também os títulos dos sermões que abrangem temáticas como a Criação, o Apocalipse e o significado das festividades santas. Mais do que apenas explicações sobre o credo dos Jardineiros de Deus, os sermões de Adam One "oferecem um comentário substancialmente sombrio na situação do grupo quando é inicialmente relegado às margens e posteriormente arrebatado por uma divisão e finalmente largamente apagado pela praga". ${ }^{12}$ Poucos críticos comentam os sermões de Adam One como uma narrativa em si, e frequentemente estudos do romance são feitos com base nos trechos de Toby e Ren. Entretanto os sermões do personagem messiânico trazem à tona um aspecto central de $O$ Ano do Dilúvio, que é seu caráter paródico.

\section{Linda Hutcheon conceitua paródia como}

um grande modo de estruturação temática e formal, envolvendo o que anteriormente chamei de processos de modelagem integrada. Como tal, é uma das formas mais frequentes de autorreferenciação textual em nosso século. Ela faz a intersecção de criação e re-criação, de invenção e crítica. ${ }^{13}$

Paródia é, então, um modus operandi de estruturação que se apresenta como tal tanto no aspecto formal do texto como no aspecto temático. Hutcheon desvincula a ideia de paródia da necessidade de produzir efeito cômico e destaca esse recurso como a ferramenta per se de obras de arte do século XX especialmente as ligadas ao pós-modernismo. Para a teórica canadense, paródia ainda se distingue da mera apropriação ou do pastiche, constituindo-se uma técnica diferenciada de outras formas de intertextualidade. Paródia torna-se, assim "imitação com inversão irônica" ${ }^{4}$, ou seja, uma repetição com diferença.
12. BERGTHALLER. “Housebreaking the Human Animal: Humanism and the Problem of Sustainability in Margaret Atwood's Oryx and Crake and The Year of the Flood", p. 738, tradução livre.

3. HUTCHEON. A Theory of Parody, p. 101, tradução livre.
14. HUTCHEON. A Theory of Parody, p. 6 , tradução livre. 
15. HUTCHEON. A Theory of Parody, p. 32, tradução livre.

16. HUTCHEON. $A$ Theory of Parody, p. 101-102, tradução livre.
Dessa forma, há sempre uma relação de duplicidade textual quando se trata de paródia. Em primeira instância, há dois textos: o texto parodiado e a paródia em si. Há também a presença de um discurso duplo por conta da presença da ironia: a paródia ao mesmo tempo reforça e reverte o discurso expresso no texto parodiado. Hutcheon, tendo em vista essa última característica, diz que paródia é "uma síntese bitextual que incorpora o velho no novo" 15 e que "pressupõe igualmente a lei e sua transgressão, ou igualmente a repetição e a diferença, e que esta é a chave para seu potencial duplo: ela pode ser igualmente conservadora e transgressora" ${ }^{16} \mathrm{O}$ texto parodiado não está sob ataque ou sendo difamado, mas sim usado como modelo. Em outras palavras, está sendo duplicado, mas essa duplicação envolve sua transformação em algo outro.

É exatamente essa a relação estabelecida nos sermões de Adam One. Há uma paródia em relação aos sermões cristãos, especialmente aqueles ligados à tradição protestante. A linguagem dos sermões, bem como seu formato, são duplicados e o leitor facilmente reconhece a estrutura desse gênero literário. No entanto, algumas alterações causam estranhamento, pois não pertencem à linguagem do gênero. A conjunção do que é familiar com o que não é remete à ideia de repetição e diferença da qual fala Hutcheon, pois é somente a partir do conhecido que o leitor consegue identificar o que está sendo parodiado, mas somente o uso da diferença é capaz de qualificar o texto como paródia.

A estrutura familiar do sermão cristão protestante, que se inicia com um cumprimento à comunidade presente (podendo aqui inserir-se comentários a respeito da rotina do grupo e testemunhos de irmãos convertidos), é seguida de uma interpretação da Bíblia e dos desígnios de Deus e concluída com uma exortação à mudança através da religião e de um louvor:

Queridos Irmãos Jardineiros na Terra que é o Jardim de Deus: que maravilha vê-los todos juntos aqui no nosso lindo Jardim no topo de edifício Eddencliff! [...] e eu espero ansiosamente pela nossa próxima refeição de Irmandade [...], cortesia de Pilar, nossa Eve Six. Nós também celebramos a promoção de Toby para professora em tempo integral. Por seu trabalho e dedicação, Toby nos mostrou que uma pessoa pode superar tantas quanto forem as experiências dolorosas e obstáculos interiores desde que tenham visto a luz da Verdade. Nós estamos orgulhosos de você, Toby. ${ }^{17}$

As Palavras Humanas de Deus falam da Criação em termos que podem ser entendidos apenas para os homens antigos. [...] Deus não pode ser absorvido na estreiteza das interpretações literais e materialistas, nem pode ser medido por medidas Humanas, pois Seus dias são eras, e milhares de eras do nosso tempo são como uma noite para Ele. ${ }^{18}$
17. ATWOOD. The Year of the Flood, p. 51, tradução livre.

8. ATWOOD. The Year of the Flood, p. 11, tradução livre. 
19. ATWOOD. The Year of the Flood, p. 53, tradução livre.

20. ATWOOD. The Year of the Flood, p. 13 , tradução livre.
Nós agradecemos a Ti, oh Deus, por nos ter feito de tal modo que nos lembre, não só do nosso ser menos Angélico, mas também dos nós de DNA e RNA que nos unem às nossas Criaturas irmãs. ${ }^{19}$

O quanto nós perdemos, queridos Irmãos Mamíferos e Irmãos Mortais! O quanto nós temos voluntariamente destruído! O quanto nós temos que restaurar dentro de nós! [...] Cantemos! ${ }^{20}$

O uso de letras maiúsculas para se referir a Deus é senso comum e esperado em um discurso religioso, mas o uso de maiúscula em "Humanas" gera uma quebra de expectativa, pois implica que os Jardineiros de Deus valorizam humanidade a ponto conferir a ela um status igual ao de Deus. A visão da supremacia divina é, assim, quebrada, pois, mesmo com o louvor final, fica registrada no texto uma perspectiva diferenciada na relação cristã homem-deus. Há uma quebra na referida tradição de colocar Deus acima da humanidade e o discurso irônico presente na paródia gera uma interpretação dupla: Adam One está então desafiando a ideia de um Deus todo-poderoso ou está apenas apresentando uma visão mais harmônica da Criação? Fica a cargo do leitor escolher uma dessas leituras, uma vez que as duas são possíveis.

Expressões como "Irmãos Mamíferos" também é outra característica que chama a atenção do leitor para o texto como duplo. Enquanto que o termo "irmãos" é algo esperado em um sermão, "mamíferos" certamente não é. Em seus sermões, Adam One manifesta sua visão de que os animais são tão importantes quanto os humanos e que seria dever desses últimos zelar pelos primeiros, razão pela qual os Jardineiros de Deus são vegetarianos e não utilizam nenhum tipo de derivado animal em suas atividades cotidianas. A frequente menção a animais como "Irmãos Mamíferos" durante os sermões, enfatizada pelo uso da letra maiúscula, é ainda mais radicalizada quando Adam One fala dos primatas como ancestrais humanos e dá explicações geológicas para a criação da Terra. Até mesmo seus títulos são paródias de títulos de sermões. Por exemplo, o primeiro, cujo nome é "Da Metodologia de Deus na Criação do Homem”, carrega em si uma estrutura paródica. Ao misturar uma forma religiosa a uma nomenclatura científica ("metodologia" remete a um método rigoroso e específico), o leitor pode ser levado a questionar tanto o discurso religioso quanto o científico.

A incorporação do discurso científico não é algo esperado de um sermão cristão. Em meio ao louvor, Adam One refere-se a estruturas de DNA e RNA, no entanto, na citação anterior, há a ideia de que Deus não pode ser mensurado pela ciência. Certamente há uma apropriação do discurso científico, mas o embate entre ciência e religião ainda permanece. Linda Hutcheon, ao fazer uma crítica acerca da poética de 
21. HUTCHEON. The Canadian Postmodern, p. 139, tradução livre.

22. Hutcheon desenvolve a noção de paradoxo pós-moderno em The Canadian Postmodern. Para a é um texto que carrega em si ensões não resolvidas, apenas

tencoes nao resolvidas, apenas Um exemplo seria a tensão entre processo/produto em uma obra literária: apesar de vários autores ós-modernos enfatizarem o processo de escrita numa obra, ela inda é um produto finalizado.

23. HUTCHEON. A Theory of Parody, p. 108, tradução livre.
Atwood, aponta para as "dualidades violentas"21 presentes na obra da escritora, dualidades essas que não se resolvem, mas que permanecem com um paradoxo pós-moderno. ${ }^{22} \hat{E}$ interessante observar então que, em relação à apropriação do discurso científico pelo discurso religioso, há uma dupla paródia nos sermões de Adam One. A segunda camada da paródia seria justamente essa dualidade de discursos: estaria Adam One de certa forma corrompendo o discurso da religião com a ciência ou mostrando que a ciência está, na verdade, subordinada a Deus? Mais uma vez, as duas leituras são possíveis em decorrência da presença da ironia.

Através do uso das noções desestabilizadoras acima, o leitor entra no papel de estabelecer uma relação entre o texto lido, o sermão de Adam One, e seu duplo, o gênero do sermão cristão. Sem seu duplo textual, os textos de Adam One não têm significado, uma vez que estes dependem daquele. Hutcheon expressa a importância do leitor para a constituição da paródia:

Essa ênfase na importância do ato interpretativo do receptor do texto foi reforçada por visões pós-modernas da paródia como performance, envolvendo um aumento do trabalho e da participação do decodificador, que é forçado a focar extensivamente em sua memória artística. ${ }^{2.3}$

Ou seja, para que a paródia se constitua como tal, é necessário que o leitor identifique o texto ou gênero a ser parodiado.
A natureza dupla do texto é necessária a fim de que a leitura da paródia ocorra. Consciente dessa duplicidade textual, o leitor é remetido à própria construção do texto. Afinal, se o texto lido é articulado em uma relação direta com um texto anterior e se suas características são apropriadas daquele texto e resignificadas para criar outro, então a textualidade fica em evidência, quebrando-se, assim, a ideia de que a literatura é uma representação direta da realidade. A partir de uma relação de familiarização e desfamiliarização, o leitor se vê diante de um paradoxo metaficcional, ou seja, sua atenção é deslocada para a estrutura do texto e sua construção.

Por desfamiliarização, utilizo aqui a apropriação que Patricia Waugh faz do conceito do formalismo russo para designar uma característica da metaficção que é a de fazer com que o leitor veja explicitamente o uso das convenções literárias realistas, percebendo que elas não são "naturais" (ou seja, uma ideia de que a narrativa realista é uma representação direta da realidade e que as convenções da narrativa realista ${ }^{24}$ são a única forma de se fazer literatura) e seja forçado a fazer uma reflexão sobre elas. Waugh considera o uso da paródia e sua relação de tensão entre familiar e não familiar:

Metaficção, no entanto, oferece igualmente inovação e familiaridade através de um retrabalho individual e desestabilização de convenções familiares. [...] A paródia (...) funciona para desfamiliarizar tais estruturas estabelecendo contra-técnicas
24. Por convenções da narrativa realista, quero dizer o uso de onisciente, por exemplo) que pretendem dar a ilusão de que narrativa em questão representa o real e que a língua consegue transmitir essa realidade de forma transparente. 
25. WAUGH. Metafiction, p. 13 tradução livre. de desestabilizar a autoridade do autor onisciente, do fechamento do final "definitivo", da interpretação definitiva. ${ }^{25}$

Através da quebra de convenções e da desfamiliarização das estruturas, o texto paródico assume uma qualidade metaficcional. Waugh considera a paródia um extremo do espectro metaficcional, pois consistiria exatamente da desestabilização estrutural das convenções realistas. O outro extremo seria o romance experimental, que trabalha, no nível do signo, com a impossibilidade de dizer da própria linguagem.

O paradoxo metaficcional, como concebido por Linda Hutcheon em Narcissistic Metafiction (mas que não se distancia muito da teorização sociocultural de Waugh), expresso na paródia, tem uma natureza dupla. Por chamar atenção para o status textual, narrativas metaficcionais quebram com a narrativa tradicional ao mesmo tempo que a endossam. Dessa forma, há duas tensões nos textos de Adam One: a tensão entre texto parodiado e paródia e a tensão metaficcional entre narrativa tradicional realista e narrativa pós-moderna. Dessa forma, é possível afirmar que há um duplo discurso paródico nos sermões de Adam One. Hutcheon afirma que

o significado final da ironia e da paródia está no reconhecimento da superposição desses níveis [um nível superficial, em primeiro plano, e um nível mais profundo, implícito no texto]. É na duplicidade igualmente da forma e do efeito pragmático ou etos que faz da paródia um importante modo de autorreflexão moderno na literatura. ${ }^{26}$

A paródia, em si, já é um discurso duplo, mas ela pode se desdobrar em outras duplicidades internas, que jazem em planos secundários de leitura. A partir de um efeito estético que chama o leitor para a autorreflexividade do texto, esses níveis se confundem no próprio texto. A associação entre os dois dá a qualidade dupla da paródia e do discurso irônico presente nela.

O duplo textual nos sermões de Adam One, por sua natureza metaficcional, podem ser lidos, dentro do romance $O$ Ano do Dilúvio, como um recurso utilizado para questionar a suposta naturalidade dos discursos da religião e da ciência. Ao fazer convergir os dois, Adam One supostamente estaria eliminando a relação de dualidade, mas, ao contrário, há na narrativa um reforço da ideia de que os dois discursos estão separados. Isso ocorre pela quebra de expectativa do leitor, que, ao se deparar com a estrutura de sermão cristão, espera dele as convenções do gênero, convenções essas que repelem o discurso da ciência como paradigma de conhecimento. A construção do discurso de Adam One, tornada explícita pela paródia, faz com o que o leitor questione a suposta naturalidade dos discursos religiosos e científico, mostrando que eles são construídos com cuidado de forma a convencer o público de suas supostas verdades. O choque entre esses dois
26. HUTCHEON. A Theory of Parody, p. 34, tradução livre. 
27. WAUGH. Metafiction, p. 22 , tradução livre. discursos, bem como a apropriação feita de um pelo outro, gera um estranhamento que posteriormente remete a uma reflexão tipicamente pós-moderna: se os discursos religiosos e científicos estão sendo construídos nesse romance, então eles o são fora dele.

A partir desse raciocínio, é possível questionar a própria noção de realidade, como faz Waugh:

Qualquer texto que dirija a atenção do leitor para seu próprio processo de construção ao frustrar as expectativas convencionais de significado e fechamento problematiza mais ou meno explicitamente os modos com que códigos narrativos - sejam "literários" ou "sociais" - artificialmente constroem mundos aparentemente "reais" e imaginários em termos de ideologias particulares que apresentam estas como transparentemente "naturais" e "eternas". ${ }^{27}$

Ao lhe ser revelado o processo de construção de um texto pelo fato de as expectativas convencionais daquele gênero não serem atendidas, o leitor pode ser levado a questionar a construção de discursos que se mostram tradicionalmente como naturais e não como construções. No caso específico do romance $O$ Ano do Dilúvio, os sermões de Adam One quebram as convenções do sermão cristão ao conjugar religião e discurso científico. Dessa forma, o discurso religioso e o discurso científico são mostrados como construtos ideológicos e não como fontes de conhecimento neutras. A leitura dos sermões de Adam One como paródia é o que permite o questionamento dessas duas instâncias dentro do romance, a partir do paradoxo metaficcional.

As instâncias do duplo textual em forma de paródia presentes em $O$ Ano do Dilúvio se apresentam em duas frentes: a primeira sendo a própria tensão de duplos textuais, ou seja, sermão cristão e texto parodiado, e a segunda, a tensão entre o discurso religioso e científico dentro da própria estrutura da paródia. O efeito da paródia no romance cria um paradoxo metaficcional que pode levar o leitor a questionar a própria construção da narrativa e dos discursos que a permeiam. Devido ao caráter irônico da paródia, que carrega em si tanto a convenção quanto a contraconvenção, o texto possui um caráter aberto, em que interpretações duplas - ou mesmo múltiplas - coexistem. Como em outros romances de Margaret Atwood, a presença do duplo textual enfatiza questões relacionadas à ficcionalidade e à metaficção.

\section{REFERÊNCIAS}

ATWOOD, Margaret. The Year of the Flood. New York, Random House, 2009

BERGTHALLER, Hannes. Housebreaking the Human Animal: Humanism and the Problem of Sustainability in Margaret Atwood's Oryx and Crake and The Year of the Flood. English Studies, London, v. 91, n. 7. 2010, p. 728-743. 
BOUSON, Brooks. "We're using up the Earth. It's almost gone": A Return to the Post-Apocalyptic Future in Margaret Atwood's The

Year of the Flood. The Journal of Commonwealth Literature 46, n. 9, 2011, p. 9-26.

BOYD, Brian. On the Origins of Stories: evolution, cognition, and fiction. Cambridge, First Harvard University Press, 2010.

HOOGHEEM, Andrew. Secular Apocalypses: Darwian Criticism and Atwoodian Floods. Mosaic, v. 45, n. 2, 2012, p. 55-71.

HUTCHEON, Linda. The Canadian Postmodern: A Study of Contemporary English-Canadian Fiction. Toronto, Oxford University Press, 1988

Narcissistic Metafiction: The Metafictional Paradox New York, Methuen, 1984.

A Theory of Parody: The Teachings of TwentiethCentury Art Forms. New York, Methuen, 1985.

LADUBOVA, Katarina. Power, Pain and Manipulation in Margaret Atwood's Oryx and Crake and The Year of the Flood. Brno Studies in English, v. 36, n. 1, 2010, p. 135-146.

MOYLAN, Tom. Scraps of the Untainted Sky: Science Fiction, Utopia, Dystopia. Oxford, Westview Press, 2000.

WAUGH, Patricia. Metafiction: The Theory and Practice of SelfConscious Fiction. London, Routledge, 1984. 